DOI: $10.22363 / 2313-1683-2019-16-2-275-278$

UDC 159.99

\title{
Transforming Psi Chi and Psychology Through Internationalization
}

\author{
Melanie M. Domenech Rodríguez
}

\author{
Utah State University \\ 2810 Old Main Hill, Logan UT, 84322-2810, United States of America
}

The benefits of diversity in education and business have been touted for decades pointing to improved problem-solving, creativity, and educational and business outcomes (Curşeu \& Pluut, 2013; Montalvo \& Reynal-Querol, 2014). Some research also points to perils of diversity such as increased conflict (Ross, 2014). But what exactly is diversity? Diversity is construed as the presence of people from diverse sociocultural backgrounds, including but not limited to race/ethnicity, gender identity, sexual orientation, socioeconomic status, religion, and ability/disability. These characteristics of diversity are internationally applicable, but how social inequities and disparities based on these characteristics are expressed is quite rooted in specific social (e.g., national) contexts.

Social categorizations, and the very conceptualization of health and illness, are socially constructed (Burton, 2015; Waters, 2010). Because psychology deals with the broad spectrum of human behavior, including mental health and illness, it is critical that we are able to understand the wide variety of human experiences and that our psychological scholarship is both accurate and benefits people equally. This is not just a general values statement, it is an ethical imperative for researchers internationally (World Medical Association, 2013). In addition to the importance of understanding human behavior in its cultural context, and acknowledging the methods and instruments of psychology as cultural artifacts (Domenech Rodríguez et al., 2018). To date, much research is WEIRD (Heinrich, Heine, \& Norenzayan, 2010), providing both a challenge but also an excellent opportunity for the field of psychology.

Psi Chi, as the International Honor Society in Psychology, has seized this opportunity to address a pressing need in psychology. Psi Chi is uniquely positioned to help fill the enormous gaps in knowledge regarding the variety of human experiences. As a society that encourages membership from the early college years, we are in an excellent position to partner with educators on college campuses to help shape the minds and hearts of

(C) Domenech Rodríguez M.M., 2019

This work is licensed under a Creative Commons Attribution 4.0 International License 
psychologists- and psychology-supporters-in-training. The society's publications, programs, scholarships, awards, grants, and other resources are vast and available to all of our members (visit www.psichi.org). Providing a global perspective from the outset of their higher education careers can transform the field by setting the expectations for an international perspective.

It is critical in the process of internationalization not to recreate the very social dynamics that have created inequities. Representation alone (i.e., diversity) is not sufficient to create a truly international organization. Power-uneven approaches to international collaborations can result in intellectual colonization, cultural imperialism, or cultural appropriation (e.g., in research, see Domenech Rodríguez et al., 2018). Practicing principles of inclusion wards off against engaging internationalization in the fashion of explorers/colonizers of the past. Inclusion is the focus on equitable participation and leveraging differences to achieve good outcomes (Roberson, 2006).

The strength of Psi Chi's approach over the past decade has been to establish true partnerships with scholars around the globe through personal contact, proactive investment, and perhaps most importantly, our own growth as an organization. International chapters have been established primarily through substantive and meaningful personal contact whereas with students or faculty. Those personal relationships allow for an ongoing communication that results in the identification of specific organizational structures or processes that are insular or outdated. Specific issues, such as the differences in psychological training across the globe, result in requirements that may not be relevant or may be impractical in settings outside the United States (e.g., that faculty advisors hold a Ph.D.). As these issues come up, the organization takes steps to identify the structural barriers to meaningful participation of an international community. The Board discusses the original intent of requirements and regulations in the context of the mission of Psi Chi and thoughtfully and deliberately discuss alternatives. Sometimes changes are as simple as internal policy shifts, whereas others have required constitutional amendments. Constitutional amendments are our highest level of difficulty in organizational change as these require Board approval and also a membership-wide vote.

In the end, I believe one of the most powerful consequences in Psi Chi's internationalization is what we model for psychologists and professionals in the field: that growth is possible and required in order to transform ourselves and our organizations in the service of "recognizing and promoting excellence in the science and application of psychology" (www.psichi.org). Becoming an international organization has meant developing and evolving our understanding of psychology, excellence, scholarship, and honor. In engaging learning and embracing change and growth, we have ensured our continued relevance to the field and to society.

\section{References}

Burton, N. (2015). The meaning of madness (2nd ed.). Oxford, United Kingdom: Acheron Press.

Curşeu, P. \& Pluut, H. (2013). Student groups as learning entities: The effect of group diversity and teamwork quality on groups' cognitive complexity. Studies in Higher Education, 38, 87-103. https:// doi.org/10.1080/03075079.2011.565122 
Domenech Rodríguez, M.M., Baumann, A.A., Vázquez, A.L., Amador-Buenabad, N.G., Franceschi Rivera, N., Ortiz-Pons, N., \& Parra-Cardona, J.R. (2018). Scaling out evidence-based interventions outside the U.S. mainland: Social justice or Trojan horse? Journal of Latina/o Psychology, 6, 329344. https://doi.org/10.1037/lat0000121

Henrich, J., Heine, S.J., \& Norenzayan, A. (2010). The weirdest people in the world? Behavioral and Brain Sciences, 33(2-3), 61-83. https://doi.org/10.1017/S0140525X0999152X

Montalvo, J.G., \& Reynal-Querol, M. (2014). Cultural diversity, conflict, and economic development. In Handbook of the Economics of Art and Culture (vol. 2, pp. 485-506). https://doi.org/10.1016/ B978-0-444-53776-8.00018-0

Roberson, Q.M. (2006). Disentangling the meanings of diversity and inclusion in organizations. Group \& Organization Management, 31, 212-236. https://doi.org/10.1177/1059601104273064

Ross, S.N. (2014). Diversity and intergroup contact in higher education: Exploring possibilities for democratization through social justice education. Teaching in Higher Education, 19, 870-881. https://doi.org/10.1080/13562517.2014.934354

Watters, E. (2010). Crazy like us: The globalization of the American psyche. New York, NY: Free Press.

World Medical Association. (2013). WMA declaration of Helsinki - Ethical principles for medical research involving human subjects. Retrieved from http://www.wma.net/en/30publications/10policies/b3/

\section{Article history:}

Received: 6 May 2019

Revised: 8 May 2019

Accepted: 30 May 2019

\section{For citation:}

Domenech Rodríguez, M.M. (2019). Transforming Psi Chi and Psychology Through Internationalization. RUDN Journal of Psychology and Pedagogics, 16(2), 275-278. http://dx.doi. org/10.22363/2313-1683-2019-16-2-275-278

\section{Bio Note:}

Melanie M. Domenech Rodriguez, Ph.D., is a Professor of Psychology at Utah State University (Logan, USA). Her research, teaching, consultation, and clinical activities are focused on advancing diversity and inclusion broadly. Her research focuses on cultural competence, cultural adaptations of evidence-based interventions, and parenting training in Latinx families. Dr. Domenech Rodríguez served as Faculty Advisor for the Utah State University Chapter of Psi Chi (2002-2015), Rocky Mountain Regional Vice-President (2005-2009), Editor of Psi Chi Journal of Psychological Research (2012-2016), and President of the Board of Directors (2018-2019). E-mail: Melanie.Domenech@usu.edu 


\title{
Преобразования Psi Chi и психологии посредством интернационализации
}

\author{
М.М. Доменек Родригес \\ Государственный университет Юты \\ Соединенные Штаты Америки, 84322-2810, штат Юта, Логан, Old Main Hill, 2810
}

\begin{abstract}
Автор полагает, что одним из самых главных достижений интернационализации Psi Chi является создание модели для психологов и профессионалов в этой области, символизирующей следующее: международный рост возможен и необходим, чтобы преобразовать себя и свои организации, служить «признанию и продвижению достижений научной и прикладной психологии» (www.psichi.org). Превращение в международную организацию означает развитие и совершенствование понимания психологии, научных свершений и почета.
\end{abstract}

\author{
История статьи: \\ Поступила в редакцию: 6 мая 2019 \\ Принята к печати: 30 мая 2019
}

\section{Для цитирования:}

Domenech Rodríguez M.M. Transforming Psi Chi and Psychology Through Internationalization (Преобразования Рsi Chi и психологии посредством интернационализации) // Вестник Российского университета дружбы народов. Серия: Психология и педагогика. 2019. Т. 16. № 2. C. 275-278. http://dx.doi.org/10.22363/2313-1683-2019-16-2-275-278

\section{Сведения об авторе:}

Доменек Родригес Мелани M., Ph.D., профессор психологии в Государственном университете Юты (Логан, США). Ее исследовательская, преподавательская, консультативная и клиническая деятельность направлены на широкое распространение принципов разнообразия и инклюзии в разных сферах, а исследования посвящены проблемам культурной компетентности, культурной адаптации и тренингам родителей в семьях латиноамериканского происхождения. Была советником отделения Psi Chi в Государственном университете штата Юты (2002-2015 гг.), вице-президентом Psi Chi от региона Роки Маунтан (2005-2009 гг.), редактором «Журнала психологических исследований Psi Chi» (20122016 гг.). В настоящее время является президентом совета директоров Psi Chi (20182019 гг.). E-mail: Melanie.Domenech@usu.edu 